\begin{tabular}{|c|c|c|}
\hline$\underset{P U B L I C A T I O N}{\operatorname{NF}}$ & $\begin{array}{c}\text { International Journal of Advanced Engineering, Management and Science } \\
\text { (IJAEMS) } \\
\text { Peer-Reviewed Journal } \\
\text { ISSN: 2454-1311 / Vol-7, Issue-6; Jun, } 2021 \\
\text { Journal Home Page: } \text { https://ijaems.com/ } \\
\text { Article DOI: https://dx.doi.org/10.22161/ijaems.76.10 }\end{array}$ & (1) \\
\hline
\end{tabular}

\title{
Financial Literacy and Spending Habits of Bachelor of Science in Accounting Information System (BSAIS) Students
}

\author{
Russel N. Fernandez, Aemee Joy C. Ignacio, Joyce Marie M. Gedo Cruz, Angie Lou A. \\ Santarina, Mauristh B. Canlapan, Richard V. Simangan
}

Master in Business Administration, Graduate School, Nueva Ecija University of Science and Technology, Philippines

Received: 09 Apr 2021; Received in revised form: 16 May 2021; Accepted: 04 Jun 2021; Available online: 16 Jun 2021

\begin{abstract}
This research described the financial literacy and spending habits of Bachelor of Science in Accounting Information System (BSAIS) students. Total enumeration sampling was utilized in choosing the 116 respondents from PHINMA Araullo University at Barangay Bitas, Cabanatuan City, Nueva Ecija, Philippines during the Academic Year 2020-2021.The respondents answered questionnaires adopted and modified by the researchers. The researchers divided the questionnaire into two parts. The first part pertains to the financial literacy of the respondents and the second part is about their spending habits as to academic, food, and personal needs. The questionnaire was a 4-point Likert Scale. The data gathered were tallied and analyzed using weighted mean, and set into tables for interpretation and analysis. Results revealed that the respondentshave good financial literacy. Likewise, they were good spender of their money as to their food, personal and academic needs.
\end{abstract}

Keywords-Accounting information system, financial literacy, food, money, spending habits.

\section{INTRODUCTION}

Financial literacy plays a major role in the lives of people, particularly the youth [1], [2], towards effective money management decisions. "Taking into consideration the fact that young individuals are a significant factor for the development of national economy, substantial improvement of young people's financial literacy is essential. Young people with a high level of financial literacy would be those who could give a greater contribution to the state economy, so it is important to research the level of financial literacy among young people" [2].Some of the factors involved in the financial literacy of the youthare their saving and spending habits [3],[4],[5]which greatly affect their current and future lives. Because financial literacy is not fully emphasized in the Philippine education system, the researchers decide to study the financial literacy and spending habits of students under the Bachelor of Science in Accounting Information System of Phinma Araullo University. The study determined the current status of the students in terms of personal finance and how the students can improve their knowledge and skills toward proper management of their finances. This study addressed matters that point to why, where, and how students under the course of "Bachelor of Science in Accounting Information System (BSAIS)" of PHINMA Araullo University manage their spending habits. Likewise, it aimed to find out how beneficial it is for a college student, specifically to BSAIS students, to understand the manner and importance of their financial literacy and spending habits so that they can have the ability to determine how and where their money goes. This study can also help them avoid committing more money management mistakes and be more confident in managing their finances. Thus, this study finds meaning and substance [6].

\section{METHODOLOGY}

The researchers used the quantitative-descriptive research design. According to [7] as cited in [8],"descriptive research is concerned with conditions, practices, structures, differences or relationships that exist, opinions 
held, processes that are going on or trends that are evidently useful in presenting facts concerning the nature and the status of everything".This study's respondents were all the 116 third-year BSAIS (Bachelor of Science in Accounting Information System) students who were enrolled at PHINMA Araullo University at Barangay Bitas, Cabanatuan City, Nueva Ecija, Philippines during the Academic Year 2020-2021. The researchers conducted the study at PHINMA Araullo University, Main campus, Cabanatuan City, Nueva Ecija, to know the saving behavior and spending habits of third-year BSAIS Students. The researcher used questionnaires as a primary instrument for gathering information from the desired respondents. The study used a questionnaire adopted from a past research study entitled, "Determinants of Saving Behavior among the University Students in Malaysia" Thung, et al. 2012[9] and "Spending Behavior of Management Students of University of Saint Louis Tuguegarao, Cagayan Abawag, et al., 2019[10]." The researchers divided the questionnaire into two parts. The first part pertains to the financial literacy of the respondents and the second part is about their spending habits as to academic, food, and personal needs. The questionnaire was a 4-point Likert Scale used to get the answers from the respondents. The data gathered were tallied and analyzed using weighted mean, and set into tables for interpretation and analysis.

\section{RESULTS AND DISCUSSION}

\section{Financial Literacy of the BSAIS Students}

Table 1. Financial Literacy of the Respondents

\begin{tabular}{|c|c|c|c|}
\hline Financial Literacy $(n=116)$ & $\mathbf{W M}$ & VI & QD \\
\hline 1. I understand how to invest my money. & 3.39 & SA & $\mathrm{E}$ \\
\hline $\begin{array}{l}\text { 2. I understand how to manage my borrowed money when there's something I want to } \\
\text { buy. }\end{array}$ & 3.52 & SA & $\mathrm{E}$ \\
\hline 3. I have a clear idea of my financial needs during retirement. & 3.11 & A & $\mathrm{G}$ \\
\hline 4. I have the ability to maintain financial records for my income and expenditure. & 3.05 & A & G \\
\hline 5. I have no difficulty in managing my money. & 2.79 & A & G \\
\hline $\begin{array}{l}\text { 6. I understand financial instruments (e.g., stock, bonds, T-bill, futures contract, option, } \\
\text { etc.) }\end{array}$ & 2.99 & A & G \\
\hline 7. I can prepare my weekly/monthly budget. & 3.26 & SA & $\mathrm{E}$ \\
\hline Overall Weighted Mean & 3.16 & $\mathbf{A}$ & $\mathbf{G}$ \\
\hline
\end{tabular}

Legend: $\boldsymbol{W M}=$ Weighted Mean, VI-Verbal Interpretation, $Q D$ - Qualitative Description

3.25-4.00 Strongly Agree (SA)- Excellent (E)

2.50-3.24 Agree (A)- Good $(G)$

1.75-2.49 Disagree $(D)$ - Poor $(P)$

1.00-1.74 Strongly Disagree(SD) - Very Poor (VP)

Table 1 shows the weighted mean and verbal interpretation of the Financial Literacy of the respondents. Respondents stated that: "I understand how to invest my money" (WM=3.39), "I understand how to manage my borrowed money when there's something I want to buy" (WM=3.52), "I have a clear idea of my financial needs during retirement" $(\mathrm{WM}=3.11)$, "I have the ability to maintain financial records for my income and expenditure" (WM=3.05), "I have no difficulty in managing my money"
(WM=2.79), "I understand financial instruments" (e.g., stock, bonds, T-bill, futures contract, option, etc.) (WM=2.99)," I can prepare my weekly/monthly budget" $(\mathrm{WM}=3.26)$. The overall weighted mean obtained was 3.16 with a verbal interpretation of "Agree", meaning that the respondents have good Financial Literacy.This finding shows that the respondent's literacy in handling their money will guide them towards good management of their money [1]. 


\section{Spending Habits of the BSAIS Students}

Table 2. Spending Habits of the Respondents

\begin{tabular}{|c|c|c|c|}
\hline Academic Purpose (n=116) & WM & VI & QD \\
\hline 1. I compare prices before I buy school supplies. & 3.55 & SA & ESH \\
\hline $\begin{array}{l}\text { 2. I prefer to buy school supplies from popular book stores such as National } \\
\text { Bookstore, Pandayan Bookshop, Expression, etc. }\end{array}$ & 2.95 & A & GSH \\
\hline $\begin{array}{l}\text { 3. I spend a large percentage of my money on review materials such as photocopies } \\
\text { / printed handouts. }\end{array}$ & 2.66 & A & GSH \\
\hline 4. I spend my money on computer shops when doing my school requirements. & 2.26 & $\mathrm{D}$ & PSH \\
\hline 5. I spend money on mobile data load, prepaid wifi load, and etc. & 3.03 & A & GSH \\
\hline Overall Weighted Mean & 2.89 & A & GSH \\
\hline Food & WM & VI & QD \\
\hline 6. I compare prices before I spend money on food. & 3.21 & A & GSH \\
\hline 7. I prefer eating meals in our house, boarding house, or apartment. & 3.41 & SA & ESH \\
\hline 8. I often try food that is new and affordable. & 3.16 & A & GSH \\
\hline Overall Weighted Mean & 3.26 & SA & ESH \\
\hline Personal Needs & WM & VI & QD \\
\hline 9. I compare prices before I buy clothes, shoes, and cosmetics. & 3.50 & SA & ESH \\
\hline 10. I usually buy pre-loved items for clothes, shoes, and bags. & 3.16 & A & GSH \\
\hline $\begin{array}{l}\text { 11. I prefer buying generic clothes, shoes, and bags because it is cheaper than } \\
\text { branded ones. }\end{array}$ & 3.27 & SA & ESH \\
\hline 12. I spend a portion of my allowance for the rent of my apartment/ boarding house. & 2.10 & $\mathrm{D}$ & PSH \\
\hline 13. I wait for clothes, bags, shoes, and cosmetics to be on sale before buying. & 3.34 & SA & ESH \\
\hline Overall Weighted Mean & 3.08 & A & GSH \\
\hline Grand Weighted Mean & $\mathbf{3 . 0 8}$ & $\mathbf{A}$ & GSH \\
\hline
\end{tabular}

Legend: WM= Weighted Mean, VI-Verbal Interpretation, QD-Qualitative Description

3.25-4.00 Strongly Agree (SA)- Excellent Spending Habits (ESH)

2.50-3.24 Agree (A)- Good Spending Habits (GSH)

1.75-2.49 Disagree (D)- Poor Spending Habits (PSH)

1.00-1.74 Strongly Disagree(SD) - Very Poor Spending Habits (VPSH)

Table 2 shows the weighted mean and verbal interpretation of spending habits in terms of Academic Purposes. Respondents stated that: "I compare prices before I buy school supplies" (WM=3.55), "I prefer to buy school supplies from popular book stores such as National Bookstore, Pandayan Bookshop, Expression, etc." (WM=2.95), "I spend a large percentage of my money on review materials such as photocopies / printed handouts" (WM=2.66), "I spend my money on computer shops when doing my school requirements" (WM=2.26), "I spend money on mobile data load, prepaid wifi load, and etc." (WM=3.03). The overall weighted mean obtained was 2.89 with a verbal interpretation of "Agree", meaning that the respondents have good spending habits in terms of academic purposes.

As to their spending habits in terms of food, the respondents stated that:"I compare prices before I spend money on food" (WM=3.21), "I prefer eating meals in our

This article can be downloaded from here: www.ijaems.com

(C)2021 The Author(s). Published by Infogain Publication.

This work is licensed under a Creative Commons Attribution 4.0 License. http://creativecommons.org/licenses/by/4.0/ 
house, boarding house or apartment" (WM=3.41), "I often try food that is new and affordable" (WM=3.16). They have excellent spending habits. The overall weighted mean obtained was 3.26 with a verbal interpretation of "Strongly Agree", meaning that the respondents have excellent spending habits in terms of Food.

In their spending habits in terms of personal needs, the respondents stated that: "I compare prices before I buy clothes, shoes, and cosmetics" (WM=3.50), "I usually buy pre-loved items for clothes, shoes, and bags" (WM=3.16), "I prefer buying generic clothes, shoes and bags because it is cheaper than branded ones" (WM=3.27), "I spend a portion of my allowance for the rent of my apartment/boarding house" $(\mathrm{WM}=2.10)$ and "I wait for clothes, bags, shoes, and cosmetics to be on sale before buying" (WM=3.34). The overall weighted mean obtained was 3.08 with a verbal interpretation of "Agree" meaning that respondents have good spending habits in terms of personal needs.

Overall, in their spending habits as to their academic purpose, food, and personal needs, the BSAIS students were a good spender.

\section{CONCLUSIONS AND RECOMMENDATION}

The 116 third-year BSAIS (Bachelor of Science in Accounting Information System) students who were enrolled at PHINMA Araullo University at Barangay Bitas, Cabanatuan City, and who are living in Nueva Ecija, Philippines [11], [12] during the Academic Year 20202021 have good financial literacy. Likewise, they are good spender of their money. However, there were items in the statements that the respondents need to improve such as "I have no difficulty in managing my money". Thus, in order to get rid of the difficulty in managing their money, the students should understand their current financial situation so they can have a strong motivation to continue managing their allowance. Second, students should be taught to create a financial plan including setting long-term and short-term goals like following the budget, then prioritize their goal, and third, stick to a budget they set to help them decide on how to save their money easily.As to the spending habits, the statements "I spend my money on computer shops when doing my school requirements", "I often try food that is new and affordable" and "I spend a portion of my allowance for the rental of my apartment/ boarding house" has the lowest mean and therefore, need to address.The management of PHINMA Araullo University should provide access to computer laboratories for all of their students so their students will not need to go to the computer shop to accomplish their school requirements. Students should spend money on foods that are affordable and avoid spending on new items because it will affect their money management. Lastly, students who are living far away from the school should rent an apartment that has low cost but gives them comfort to study.

\section{REFERENCES}

[1] Garg, N., \& Singh, S. (2018). Financial literacy among youth. International Journal of Social Economics. Emerald Group Publishing Ltd. https://doi.org/10.1108/IJSE-112016-0303.

[2] Caplinska, A., \& Ohotina, A. (2019). Analysis of financial literacy tendencies with young people. Entrepreneurship and Sustainability Issues, 6(4), 1736-1749. https://doi.org/10.9770/jesi.2019.6.4(13)

[3] Jeevitha, P., \& Priya, \& R. K. (2019). a Study on Saving and Spending Habits of College Students With Reference To Coimbatore City. International Journal of Research and Analytical Reviews, 6(1), 463-466.

[4] Pp, A. (2019). A Study on Saving and Spending Habit of Youth with Special Reference to Thrissur District. International Journal of Research and Analytical Reviews, 5(9), 463-466. Retrieved from Http://ijrar.com/.

[5] Priya, R. K. (2019). A Study on Saving and Spending Habits of College Students. International Journal of Research and Analytical Reviews Research, 6(1), 463-466.

[6] Subia, G. (2018) Comprehensible Technique in Solving Consecutive Number Problems in Algebra. Journal of Applied Mathematics and Physics, 6, 447-457. doi: 10.4236/jamp.2018.63041.

[7] Creswell, J.W. (2007) Educational Research, Planning, Conducting and Evaluating Quantitative and Qualitative Research. University of Nebraska, Merril, Prentice-Hall, Upper Saddle River.

[8] Mina, J.C., Barlis, P.T., Vega, N.C. and Subia, G.S. (2019) Corporate Social Responsibilities of Selected Resorts in Cabanatuan City, Nueva Ecija, Philippines. Open Access Library Journal, 6: e5292. https://doi.org/10.4236/oalib.1105292

[9] Thung, C., et al. (2012). Determinants Oof Saving Behaviour among the University Students in Malaysia.

[10] Abawag, C., et al. (2019). Spending Behavior of Management Students. Research Paper. Senior High School, University of Saint Louis, Tuguegarao City, Cagayan.

[11] Subia, G. S., Mangiduyos, G. P., \& Turgano, J. B. D. (2020). Emergency Preparedness of Novo Ecijanos. Open Journal of Social Sciences, 8, 1723.https://doi.org/10.4236/jss.2020.83003

[12] Mina, J.C., Barlis, P.T., Vega, N.C. and Subia, G.S. (2019) Corporate Social Responsibilities of Selected Resorts in Cabanatuan City, Nueva Ecija, Philippines. Open Access Library Journal, 6: e5292. https://doi.org/10.4236/oalib.1105292 